\title{
Article
}

\section{Rural and Urban Land Tourism and Destination Image: A Dual-Case Study Approach Examining Energy-Saving Behavior and Loyalty}

\author{
Wei Zheng ${ }^{1}$, Hongliang Qiu ${ }^{2,3, * \mathbb{D}}$, Alastair M. Morrison ${ }^{4}$, Wei Wei ${ }^{5}$ and Xihua Zhang ${ }^{6}$ \\ 1 School of Tourism and Foreign Languages, Tourism College of Zhejiang, Hangzhou 311231, China; \\ vickiz@tourzj.edu.cn \\ 2 School of Business Administration, Tourism College of Zhejiang, Hangzhou 311231, China \\ 3 Zhejiang Academy of Culture \& Tourism Development, Hangzhou 311231, China \\ 4 Department of Marketing, Events and Tourism, Faculty of Business, Greenwich Business School, Old Royal \\ Naval College, Park Row, Greenwich, London SE10 9LS, UK; a.morrison@greenwich.ac.uk \\ 5 Department of Hospitality Services, Rosen College of Hospitality Management, University of Central Florida, \\ Orlando, FL 32819, USA; Wei.Wei@ucf.edu \\ 6 School of Cooperative Economics, Zhejiang Institute of Economics and Trade, Hangzhou 310018, China; \\ shiwar668@zjiet.edu.cn \\ * Correspondence: qiuhongliang1127@163.com
}

Citation: Zheng, W.; Qiu, H.; Morrison, A.M.; Wei, W.; Zhang, X. Rural and Urban Land Tourism and Destination Image: A Dual-Case Study Approach Examining

Energy-Saving Behavior and Loyalty. Land 2022, 11, 146. https://doi.org/ 10.3390/land11020146

Academic Editor: Antonio Raschi

Received: 29 December 2021

Accepted: 16 January 2022

Published: 18 January 2022

Publisher's Note: MDPI stays neutral with regard to jurisdictional claims in published maps and institutional affiliations.

Copyright: (C) 2022 by the authors. Licensee MDPI, Basel, Switzerland. This article is an open access article distributed under the terms and conditions of the Creative Commons Attribution (CC BY) license (https:// creativecommons.org/licenses/by/ $4.0 /$ )

\begin{abstract}
Although the significance of destination image is acknowledged, its effect on tourist reactions, especially energy-saving behavior, remains unknown. This research aimed to explore tourist energy-saving behavior (TESB) and loyalty (TL) in a rural land context by using the cognitionaffect-behavior (CAB) model. The findings indicated: (1) destination image positively and directly influenced TESB and TL; (2) relationship quality variables, i.e., tourist satisfaction and destination trust, positively and separately mediated the associations of destination image with TESB and TL; and (3) a cross-validation approach of rural and urban cases documented support for the research findings. This study extends the destination image literature by introducing the CAB model and the cross-validation approach to examine energy-saving behavior and loyalty. It offers guidance and a reference for tourism destination practitioners to promote energy-saving behavior and loyalty through the enhancement of destination image and relationship quality.
\end{abstract}

Keywords: tourist energy-saving behavior (TESB); tourist loyalty (TL); destination image (DI); relationship quality; cognition-affect-behavior (CAB) model; cross-validation; Yucun Village; Anji County; Hangzhou; China

\section{Introduction}

Rural land and tourism, with their enduring traditional and rustic appeals, attract tourists constantly seeking authentic experiences [1]. They are enjoying greater popularity during the post-pandemic stage, where tourists find themselves more satisfied with stress relief and rejuvenation because of rural tourism's nature-based environments, wellbeingthemed activities and safer surroundings with less likelihood of coronavirus transmission $[2,3]$. Rural tourism is rising to a strategic position, contributing greatly to revitalizing local craftsmanship, reviving declining rural productivity and invigorating socio-economic development [4]. As it continues to attract attention, how to attain desirable economic, social and environmental sustainability is a key concern for practitioners and scholars [5].

Acknowledged as a key priority for the lands within tourism destinations, sustainability helps to achieve natural resources preservation, economic continuity and tourist identification and commitment [6]. It attaches more significance to rural tourism, which with the guidance of sustainability, can harvest long-term improvement of environmental protection, social justice and cultural integrity [7]. The academic interest in rural land and 
tourism sustainability is growing rapidly. An and Alarcón (2020) conducted a systematic review based on the Web of Science database of articles on sustainable rural tourism from 2009 to 2019 and found the destination image of rural tourism was an important factor impacting tourist satisfaction and loyalty and driving sustainable rural tourism [8].

Destination image plays an essential role in evaluating tourist affective responses [1] and helps rural destinations to gain competitive advantages [6]; however, researchers have concentrated on cities [9], while rural destination studies are far from sufficient. Destination image as antecedent leading to outcomes of tourist behaviors is the most researched areas in relevant studies [10]. Among these behavioral outcomes, tourist loyalty is often driven by satisfaction and trust evoked by destination image [11]. Nevertheless, much less effort has been made to investigate the connection between destination image and pro-environmental behavior $[12,13]$ and energy-saving behavior.

Concerns are growing with global warming and consequences of excessive carbon emissions, and strategies are being suggested to slow, minimize and possibly reverse tourism-related damage to optimize environmental protection [14]. Sustainable consumption by adjusting tourist behavior is beneficial to destination sustainability [15]. One effective solution is educating tourists to engage in energy-saving. Energy-saving helps reduce energy consumption, promotes carbon reduction and furthers sustainability [16], especially for rural tourism pursuing energy efficiency and land ecological sustainability [1]. Although energy-saving studies are now more frequent [17], the potential connections with destination image remain unknown. However, if addressed, this will enrich the current literature and contribute to the sustainable development of rural land.

The cognition-affect-behavior $(\mathrm{CAB})$ model delineates the individual behavior formation process that is influenced by cognition and affects [18]. This classic paradigm has been widely used, including with pro-environmental behavioral outcomes, including investigating consumer intentions to participate in hotel linen reuse programs [19]. Guided by the $\mathrm{CAB}$ model, there is an opportunity to explore energy-saving and loyalty through better comprehending the destination image and tourist behaviors in rural contexts.

A cross-validation approach using two cases was conducted. Aside from the rural context, tourism is now a significant component of urban economies [20]. Inherently different from geographically demarcated rural tourism and shaped by economic dynamics and political strategies, urban tourism is becoming a highly important, worldwide form of tourism in the form of large-scale infrastructure and postmodern consumerist spaces to attract tourists [21,22].

Based on these arguments, this research aimed to test the robustness, as well as provide a solid reference for the formation of tourist energy-saving behavior and loyalty by the cross-validation results from an urban setting. Therefore, the objectives of the research were to: (1) apply the cognition-affect-behavior (CAB) model to analyze tourist energy-saving behavior and loyalty; (2) test the mediating roles of tourist satisfaction and destination trust; and (3) use the cross-validation method to identify the influence of destination image on tourist energy-saving behavior and loyalty in both rural and urban land contexts.

\section{Literature Review and Hypotheses Development}

\subsection{Cognition-Affect-Behavior Model}

Proposed by Fishbein and Ajzen (1980) and developed by Weiner (1986), the cognitionaffect-behavior (CAB) model depicts the behavior formation process shaped by the interaction of individuals and their environments [23-25]. It holds that cognition working as an antecedent activates affect, which subsequently impacts behavior [26].

The CAB model enjoys wide application, including in consumer brand selection [18], education services [27], telecommunication services [28], hotel green initiatives [19], overall customer service experiences in ethnic restaurants [29], green marketing [30] and social networking site reviews [31].

In this research, destination image represented cognition; relationship quality (i.e., tourist satisfaction and destination trust) belonged to affect; and energy-saving behavior 
and loyalty represented behavior. It was proposed that destination image acted as a cognitive factor evoking tourist satisfaction and destination trust (affect), which fostered energy-saving behavior and loyalty (behavior).

\subsection{Hypotheses Development}

\subsubsection{Cognition: Destination Image}

Destination image is the sum of knowledge, beliefs, feelings, impressions and ideas that a tourist holds about a specific destination [32]. Destination image formation evolved for decades with varying dimensions, including induced and organic images, primary and secondary images, to cognitive, affective, and conative images and overall image [33], among which the perspective of the overall image is noted since destination image is described as an overall evaluative construct measuring tourists' holistic impressions of a destination [34]. In spite of various definitional views on image components and formation [35], there is a tendency among researchers to favor overall image as it emphasizes the formative and complex nature of destination image; in other words, overall image as a holistic concept encompasses more than image attributes and demonstrates a strong potential as the proxy for destination image [36]. Afshardoost and Eshaghi (2020) employed a meta-analysis to synthesize the dimensions and classifications of destination image based on 87 studies from major academic databases, including on Elsevier, Taylor \& Francis, Emerald, SAGE journals and Online Wiley Library, and noted that the majority of studies (63 articles) preferred overall image as a higher-order construct [37]. It is noteworthy that overall image has been applied and synonymously used with destination image in the previous tourism literature [38]. Consequently, this study adopted the overall image to conduct the destination image research.

The representations of destination image construction included primary (e.g., previous experience) and secondary sources (i.e., induced, autonomous and organic sources), both of which contribute to tourist perceived images of a destination [39]. As an important element of destination branding, the significance of a positive destination image is manifested in greater attractiveness and stronger revisit intentions [40].

Destination image research has had a focus on pre-trip images and their impacts on travel decision-making, behavioral intentions and destination preferences [37,41]. The specific contexts have been cities [42], islands [43], international sporting events [10] and websites [44], with rural destinations receiving less attention.

According to the $\mathrm{CAB}$ model, it has been confirmed that destination image exerts a positive influence on destination satisfaction and trust [45]. Hence, the research posited that destination image leads to tourist satisfaction and destination trust, and the corresponding hypotheses were:

Hypotheses 1 (H1). Destination image positively and directly influences tourist satisfaction.

Hypotheses 2 (H2). Destination image positively and directly influences destination trust.

\subsubsection{Affect: Tourist Satisfaction and Destination Trust}

Relationship marketing highlights developing, maintaining and strengthening relationships with customers [46]. Due to its vital role in tourism destinations, relationship marketing gained attention from practitioners and academics [47]. Scholars examined it in various domains and acknowledged that assessing the strength of a relationship is of critical importance when performing relationship marketing research [48].

As an element of successful marketing [49], relationship quality is generally regarded as a multi-dimensional, distinct, but related construct [50]. Two of its mostly examined variables are trust and satisfaction, each being emotional states arising in response to interactive experiences [51].

The consumer satisfaction literature shows an increasing interest in different scenarios [52]. In tourism, satisfaction is considered as emotional responses people have toward experiences of travel-related behaviors [53]. Satisfaction is vital to destination marketing 
for its powerful influence on choices of destinations, consumption of services and products and decisions to revisit [1].

Trust as a key concept in marketing has been studied in various contexts. In tourism, destination trust is derived from tourist perceptions of honesty, benevolence and competence of residents and local institutions and is likely to cause loyalty, travel intentions and repeat visits [54].

Based on the above arguments, the research regards satisfaction and destination trust as the two variables for destination-tourist relationship quality.

Satisfaction and trust help destinations establish and retain long-term relationships with tourists [55]. Trust is an accumulating emotional evaluation greater than satisfaction, which is an important origin of trust [56]. The relationship between satisfaction and trust has been well attested. Tourist satisfaction is positively related to trust when shopping [49]. Overall satisfaction has a positive influence on trust in rural tourism [47]. Accordingly, this research put forward the following hypothesis:

Hypotheses 3 (H3). Tourist satisfaction positively and directly influences destination trust.

Following the $\mathrm{CAB}$ model, the linkage between affect and behavior has been empirically emphasized. Consumer satisfaction and trust have a positive influence on loyalty in rural lodging [57]. Moreover, positive relationships of satisfaction and trust with proenvironmental behavior have been detected [58,59]. Given this evidence, the hypotheses were proposed below:

Hypotheses 4 (H4). Tourist satisfaction positively and directly influences energy-saving behavior.

Hypotheses 5 (H5). Destination trust positively and directly influences energy-saving behavior.

Hypotheses 6 (H6). Tourist satisfaction positively and directly influences loyalty.

Hypotheses 7 (H7). Destination trust positively and directly influences loyalty.

\subsubsection{Behavior: Energy-Saving Behavior and Tourist Loyalty}

Energy-saving behaviors refer to "individuals' attempts to reduce overall energy use" [17]. Daily energy-saving behaviors include regulating thermostat settings to save heat, turning off lights when leaving and closing off unused rooms [60]. These behaviors have been examined for households [61], workplaces [62], hotels [63], dormitories [64] and colleges [65] but are much less investigated in tourism. Being one of the largest energy users, tourism accounts for considerable global carbon emissions mainly through transportation, especially aviation, amenity provision and supporting facilities at destinations [66]. Tourists contribute greatly to the industry's energy consumption. Accordingly, their energy-saving practices could foster more environmentally sustainable tourism [16]. However, as far as the authors know, little research has touched upon this behavior. Therefore, it is worthwhile to examine tourist energy-saving behavior.

Though energy-saving behavior appears infrequently, loyalty is often explored in the destination image literature. Loyalty is the support of firms and commitment to specific products, places, brands, etc., mainly through rebuying products and services, revisiting, recommending and positive word-of-mouth [67]. Loyalty is vital in determining the success of a destination [41]. Loyalty can make a major contribution to destination competitiveness [68].

The prior literature has found that destination image has a direct bearing on travel behavior [69], such as intentions to visit [70], intentions to recommend and revisit [9], loyalty [57] and environmentally responsible behavior [71], with energy-saving behavior scarcely discussed.

The impact of destination image on energy-saving behavior is unexplored. However, the previous literature reveals the direct and positive influence of pro-environmental destination images on pro-environmental behavior [12,13]. Given that energy-saving behavior falls into pro-environmental behavior [72], this research suggested the following hypotheses: 
Hypotheses 8 (H8). Destination image positively and directly influences energy-saving behavior. Hypotheses 9 (H9). Destination image positively and directly influences loyalty.

\subsection{Conceptual Model}

Based on the literature review and hypotheses, the conceptual model for this research is presented in Figure 1.

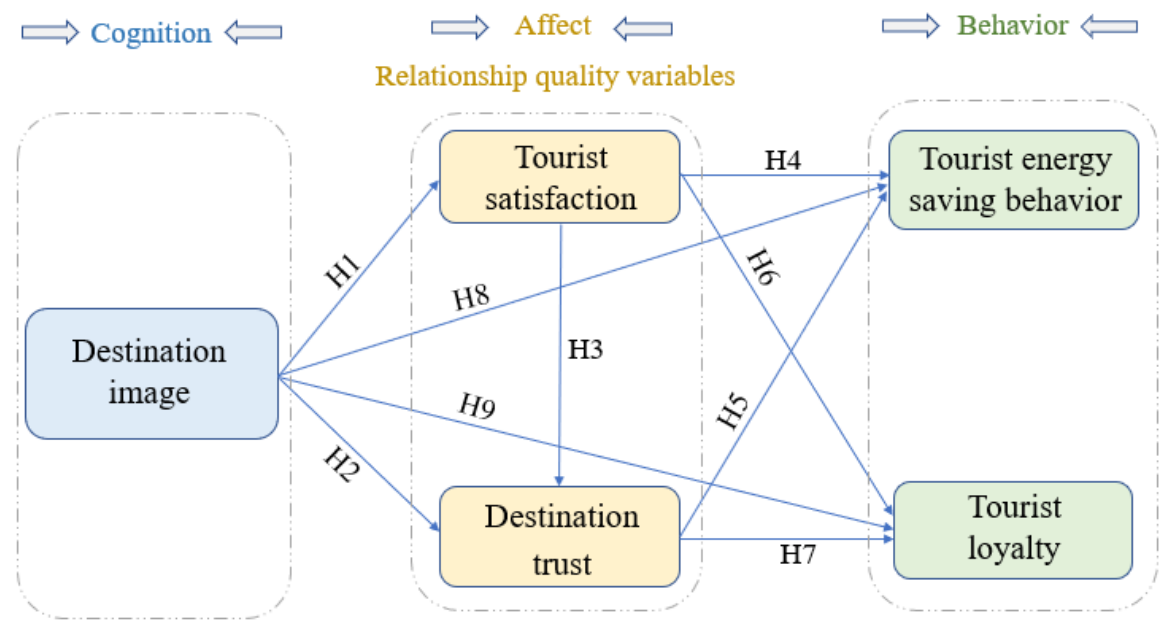

Figure 1. Conceptual model.

\section{Method}

\subsection{Measurement}

Multiple well-identified and rigorously validated items with modification were employed to measure each construct for this research. The detailed measurements are shown in Table 1. Each item, except for demographic characteristics, was measured on a five-point Likert scale from "strongly disagree" to "strongly agree".

Table 1. The detailed measurement of this study.

\begin{tabular}{|c|c|c|c|}
\hline Construct & Item & Item Label & Source \\
\hline \multirow{3}{*}{$\begin{array}{l}\text { Destination } \\
\text { image }\end{array}$} & I have a good impression of $\mathrm{X} / \mathrm{Y}$. & DI1 & \multirow{3}{*}{$\begin{array}{l}\text { Nguyen and } \\
\text { Leblanc (2001) } \\
\text { [73] }\end{array}$} \\
\hline & In my opinion, $\mathrm{X} / \mathrm{Y}$ has a good image in the minds of tourists. & DI2 & \\
\hline & I believe that $X / Y$ has a better image than its competitors. & DI3 & \\
\hline \multirow{3}{*}{$\begin{array}{l}\text { Tourist } \\
\text { satisfaction }\end{array}$} & Compared to my expectations, I am satisfied with my visit to X/Y. & TS1 & \multirow{3}{*}{$\begin{array}{l}\text { Kim and Park } \\
(2017)[74]\end{array}$} \\
\hline & $\begin{array}{l}\text { I am satisfied with my visit to } X / Y \text {, considering the invested time and } \\
\text { effort I spent on it. }\end{array}$ & TS2 & \\
\hline & Overall, I am satisfied with my visit to X/Y. & TS3 & \\
\hline \multirow{4}{*}{ Destination trust } & I trust $\mathrm{X} / \mathrm{Y}$. & DT1 & \multirow{4}{*}{$\begin{array}{l}\text { Wu et al. (2018); } \\
\text { Han et al. (2018) } \\
{[75,76]}\end{array}$} \\
\hline & $\mathrm{X} / \mathrm{Y}$ takes care of my needs as a tourist. & DT2 & \\
\hline & I have confidence in X/Y. & DT3 & \\
\hline & $\mathrm{X} / \mathrm{Y}$ is reliable. & DT4 & \\
\hline Tourist & I saved energy at $\mathrm{X} / \mathrm{Y}$ & TESB 1 & \multirow{3}{*}{$\begin{array}{l}\text { Lopes et al. } \\
\text { (2019) [77] }\end{array}$} \\
\hline \multirow{3}{*}{$\begin{array}{c}\text { energy-saving } \\
\text { behavior }\end{array}$} & Saving energy inputs during travel at $\mathrm{X} / \mathrm{Y}$ is a natural behavior for me. & TESB 2 & \\
\hline & I have implemented procedures to save energy at X/Y. & TESB 3 & \\
\hline & I will recommend $X / Y$ to my friends and relatives. & TL1 & \multirow{4}{*}{$\begin{array}{l}\text { Lee et al. (2014); } \\
\text { Lee (2016) } \\
{[78,79]}\end{array}$} \\
\hline \multirow{3}{*}{ Tourist loyalty } & I will revisit $X / Y$ again in the future. & TL2 & \\
\hline & I will say positive things about $X / Y$ to other people. & TL3 & \\
\hline & I will keep visiting $X / Y$ in the future. & TL4 & \\
\hline
\end{tabular}

Note: $\mathrm{X}=$ Anji as rural destination; $\mathrm{Y}=$ Hangzhou as urban destination

\subsection{Pretest of the Measurements}

Translation and back-translation between Chinese and English were used for the survey. A pretest was performed by eight experts (including four destination practitioners and 
four tourism scholars) responsible for reviewing the content validity and later conducted with a sample of 40 qualified Chinese tourists. The scale showed acceptable reliability (Cronbach's Alpha > 0.7) and validity (each standard factor loading $>0.5$ ).

\subsection{Sample and Data Collection}

With regard to the rural case, Anji County $\left(30^{\circ} 38^{\prime} 27.01^{\prime \prime} \mathrm{N}, 119^{\circ} 40^{\prime} 31.53^{\prime \prime} \mathrm{E}\right)$, northwest of Zhejiang Province, China, was selected. It has received multiple recognitions, including the UN Habitat Scroll of Honour, China's first ecological county, national pilot area of ecological civilization construction, the Sustainable Development Experimental Zone and national demonstration county of leisure agriculture and rural tourism [80]. Its demonstration site, Yucun Village, is the birthplace of the idea "clear waters and lush mountains are invaluable assets" proposed by President Xi Jinping, and the country's first eco-tourism and rural holiday scenic area, as well as ideal conference sites with this theme [81]. Recently, Yucun Village was one of the Best Tourism Villages 2021 by UNWTO [82]. Based on this evidence, Anji County is representative and well-qualified for the survey. Therefore, the rural case study was conducted at Anji County with Yucun Village as the main site.

Due to the continuing impact of the COVID-19 pandemic, the number of international inbound tourists to China was minimal because of perceived epidemic risks, international travel restrictions and complex entry quarantine regulations. As a result, domestic tourists were much more predominant in the survey area. Therefore, the survey focused on domestic tourists as respondents; foreign tourists were not included. An on-site survey was conducted in October 2021 by five trained assistants, and a total of 400 questionnaires were collected. Of these, 373 usable responses were identified with a usable response rate of 93.25\%. Among the respondents, males accounted for $48.0 \%$ while females for $52.0 \%$; aged 20 below occupied $9.1 \% ; 20-29,20.4 \% ; 30-39,33.2 \% ; 40-49,18.0 \%$; and 50 and above, $19.3 \%$. Middle school and below for education was $13.1 \%$; high school/secondary specialized school/technical school, $15.8 \%$; vocational college, $21.2 \%$; undergraduate, $39.9 \%$; and postgraduate and above, $9.9 \%$. The values of univariate skewness statistics ranged from -1.179 to -0.022 , and the values of univariate kurtosis statistics ranged from -0.556 to 2.467, which showed that the data met the skewness and kurtosis requirements [83].

\section{Results}

\subsection{Common Method Variance Test}

This study employed multiple approaches to control common method variance (CMV) since cross-sectional data were used [84]. First, Harman's single-factor test was performed using exploratory factor analysis (EFA) to assess the possible problem of CMV. The EFA results produced a multi-factor structure accounting for $81.53 \%$ of the total variance. The first factor occupied $32.53 \%$ of the variance, which was below the threshold of $50 \%$. Second, the test compared the chi-square and $\mathrm{df}$ of a multi-dimensional model (i.e., the proposed measurement model) against the chi-square and $\mathrm{df}$ of a single-factor model (i.e., assumes one latent factor accounts for all constructs). The results showed that the proposed measurement model fit better than the common factor one $\left(\Delta \chi^{2}=2847.723, \Delta \mathrm{df}=10, p<0.001\right)$. Therefore, CMV was not a problem in this study [85].

\subsection{Measurement Model Test}

As recommended by Anderson and Gerbing (1988), before assessing the hypotheses via structural equation modeling (SEM), the two-step modeling method was employed to initially formulate a measurement model through confirmatory factor analysis (CFA) [86]. AMOS was applied to perform the analysis. Then, CFA was used first to estimate the reliability and validity of measurement reliability and validity, and the results of the measurement model demonstrated an acceptable model fit $\left(\chi^{2} / \mathrm{df}=1.841\right.$, RMR $=0.012$, RMSEA $=0.048$, $\mathrm{GFI}=0.941, \mathrm{NFI}=0.955, \mathrm{IFI}=0.979, \mathrm{TLI}=0.974, \mathrm{CFI}=0.979, \mathrm{SRMR}=0.0376)$.

Table 2 shows that for each construct, the composite reliability (CR) was above 0.884 , exceeding the threshold of 0.70 [87]. Standardized factor loadings of each item ranged 
from 0.737 to 0.902 , which were significant $(p<0.001)$. The average variance extracted (AVE) values were between 0.713 and 0.783 , exceeding the recommended cut-off point of 0.50 . The results indicated that sufficient convergent validity was demonstrated [88]. Discriminant validity was estimated by the comparison of the square root of the AVEs of each construct with the correlations between pairs of latent variables [89]. Table 3 provides strong evidence for discriminant validity. The results demonstrated that the measurement model was both reliable and valid.

Table 2. Measurement model results.

\begin{tabular}{|c|c|c|c|c|c|c|c|c|}
\hline \multirow[b]{2}{*}{ Construct } & \multicolumn{4}{|c|}{ Case1 (Rural Destination) } & \multicolumn{4}{|c|}{ Case2 (Urban Destination) } \\
\hline & Loading & T-Values & CR & AVE & Loading & T-Values & CR & AVE \\
\hline DI & & & 0.884 & 0.717 & & & 0.878 & 0.706 \\
\hline DI1 & 0.793 & 17.742 & & & 0.779 & 16.826 & & \\
\hline DI2 & 0.882 & 19.663 & & & 0.893 & 18.86 & & \\
\hline DI3 & 0.863 & - & & & 0.845 & - & & \\
\hline TS & & & 0.915 & 0.783 & & & 0.902 & 0.755 \\
\hline TS1 & 0.878 & 22.703 & & & 0.823 & 19.931 & & \\
\hline TS2 & 0.894 & 23.282 & & & 0.896 & 22.142 & & \\
\hline TS3 & 0.882 & - & & & 0.886 & - & & \\
\hline DT & & & 0.908 & 0.713 & & & 0.924 & 0.752 \\
\hline DT1 & 0.737 & 16.613 & & & 0.862 & 19.924 & & \\
\hline DT2 & 0.88 & 21.989 & & & 0.902 & 21.267 & & \\
\hline DT3 & 0.893 & 22.502 & & & 0.881 & 20.581 & & \\
\hline DT4 & 0.859 & & & & 0.821 & - & & \\
\hline TESB & & & 0.893 & 0.737 & & & 0.897 & 0.744 \\
\hline TESB1 & 0.839 & 18.774 & & & 0.831 & 19.045 & & \\
\hline TESB2 & 0.902 & 19.898 & & & 0.905 & 20.6 & & \\
\hline TESB3 & 0.832 & - & & & 0.849 & - & & \\
\hline $\mathrm{TL}$ & & & 0.917 & 0.734 & & & 0.916 & 0.733 \\
\hline TL1 & 0.794 & 18.88 & & & 0.743 & 17.587 & & \\
\hline TL2 & 0.875 & 22.259 & & & 0.896 & 24.724 & & \\
\hline TL3 & 0.889 & 22.819 & & & 0.883 & 24.052 & & \\
\hline TL4 & 0.866 & - & & & 0.892 & - & & \\
\hline
\end{tabular}

Note: DI = Destination image; TS = Tourist satisfaction; DT = Destination trust; TESB = Tourist energy-saving behavior; $\mathrm{TL}=$ Tourist loyalty $\mathrm{CR}=$ composite reliability; $\mathrm{AVE}=$ average variance extracted .

Table 3. Results of discriminant validity.

\begin{tabular}{|c|c|c|c|c|c|c|c|c|c|c|}
\hline \multirow{2}{*}{ Construct } & \multicolumn{5}{|c|}{ Case1 (Rural Destination) } & \multicolumn{5}{|c|}{ Case2 (Urban Destination) } \\
\hline & DI & TS & DT & TESB & TL & DI & TS & DT & TESB & TL \\
\hline DI & [0.847] & & & & & [0.840] & & & & \\
\hline TS & 0.176 & [0.885] & & & & 0.202 & [0.869] & & & \\
\hline DT & 0.319 & 0.285 & [0.844] & & & 0.306 & 0.258 & [0.867] & & \\
\hline TESB & 0.237 & 0.204 & 0.228 & {$[0.858]$} & & 0.215 & 0.199 & 0.213 & [0.863] & \\
\hline $\mathrm{TL}$ & 0.258 & 0.321 & 0.285 & 0.244 & [0.857] & 0.292 & 0.259 & 0.333 & 0.232 & [0.856] \\
\hline
\end{tabular}

Note: $\mathrm{DI}=$ Destination image; $\mathrm{TS}=$ Tourist satisfaction; $\mathrm{DT}=$ Destination trust; TESB $=$ Tourist energy-saving behavior; $\mathrm{TL}=$ Tourist loyalty.

\subsection{Structural Model Test}

The direct hypotheses were assessed by structural equation modeling (SEM). The fit indices showed that the model offered an acceptable fit $\left(\chi^{2} / \mathrm{df}=1.874, \mathrm{RMR}=0.015\right.$, RMSEA $=0.048$, GFI $=0.939, \mathrm{NFI}=0.954, \mathrm{IFI}=0.978, \mathrm{TLI}=0.973, \mathrm{CFI}=0.978, \mathrm{SRMR}=0.0447)$. Table 4 delineates the results of the direct hypothesized links of the structural model. The 
findings supported all nine hypothesized direct links. Specifically, destination image had a significant and positive impact on tourist satisfaction $(\beta=0.176, p<0.01)$ and destination trust $(\beta=0.277, p<0.001)$. Hence, $\mathrm{H} 1$ and $\mathrm{H} 2$ were supported. Tourist satisfaction exerted a significant and positive influence on destination trust $(\beta=0.237, p<0.001)$, tourist energysaving behavior $(\beta=0.138, p<0.05)$ and tourist loyalty $(\beta=0.247, p<0.001)$. This meant H3, H4 and H6 were confirmed. Destination trust was positively related to tourist energysaving behavior $(\beta=0.136, p<0.05)$ and tourist loyalty $(\beta=0.164, p<0.01)$, supporting $\mathrm{H} 5$ and H7. Additionally, the direct effect of destination image on tourist energy-saving behavior $(\beta=0.173, p<0.01)$ and tourist loyalty $(\beta=0.164, p<0.01)$ was verified, thus supporting $\mathrm{H} 8$ and $\mathrm{H} 9$.

Table 4. Structural model assessment and hypothesis test outcome.

\begin{tabular}{ccccc|ccc}
\hline \multirow{2}{*}{ Hypotheses } & \multirow{2}{*}{ Path } & \multicolumn{2}{c|}{ Case1 (Rural Destination) } & \multicolumn{2}{c}{ Case2 (Urban Destination) } \\
\cline { 3 - 8 } & & $\begin{array}{c}\text { Standardized } \\
\text { Coefficient }\end{array}$ & T-Value & Results & $\begin{array}{c}\text { Standardized } \\
\text { Coefficient }\end{array}$ & T-Value & Results \\
\hline H1 & DI $\rightarrow$ TS & $0.176^{* *}$ & 3.078 & Supported & $0.202^{* * *}$ & 3.501 & Supported \\
H2 & DI $\rightarrow$ DT & $0.277^{* * *}$ & 4.978 & Supported & $0.264^{* * *}$ & 4.65 & Supported \\
H3 & TS $\rightarrow$ DT & $0.237^{* * *}$ & 4.344 & Supported & $0.205^{* * *}$ & 3.684 & Supported \\
H4 & TS $\rightarrow$ TESB & $0.138^{*}$ & 2.379 & Supported & $0.136^{*}$ & 2.329 & Supported \\
H5 & DT $\rightarrow$ TESB & $0.136^{*}$ & 2.242 & Supported & $0.135^{*}$ & 2.253 & Supported \\
H6 & TS $\rightarrow$ TL & $0.247^{* * *}$ & 4.425 & Supported & $0.162^{* *}$ & 2.926 & Supported \\
H7 & DT $\rightarrow$ TL & $0.164^{* *}$ & 2.828 & Supported & $0.235^{* * *}$ & 4.109 & Supported \\
H8 & DI $\rightarrow$ TESB & $0.173^{* *}$ & 2.884 & Supported & $0.149^{*}$ & 2.473 & Supported \\
H9 & DI $\rightarrow$ TL & $0.164^{* *}$ & 2.882 & Supported & $0.19^{* * *}$ & 3.332 & Supported \\
\hline
\end{tabular}

Note: ${ }^{*} p<0.05,{ }^{* *} p<0.01,{ }^{* * *} p<0.001$. DI $=$ Destination image; TS $=$ Tourist satisfaction; DT $=$ Destination trust $\mathrm{TESB}=$ Tourist energy-saving behavior; $\mathrm{TL}=$ Tourist loyalty.

The mediating effect was examined by the bootstrapping approach in AMOS. The number of bootstrap samples was set to 5000, adopting bias-corrected confidence intervals of $95 \%$. As shown in Table 5, a significant specific mediating effect was identified for destination image on tourist energy-saving behavior through tourist satisfaction $(\beta=0.021$; $\mathrm{CI}=(0,0.072) ; p<0.05)$, providing support for the $\mathrm{DI} \rightarrow \mathrm{TS} \rightarrow \mathrm{TESB}$ path. All other specific indirect effects are presented in Table 5.

Table 5. Specific mediation test results.

\begin{tabular}{|c|c|c|c|c|c|c|c|c|c|c|}
\hline \multirow{2}{*}{$\begin{array}{c}\text { Mediating } \\
\text { Hypothesized Path }\end{array}$} & \multicolumn{5}{|c|}{ Case1 (Rural Destination) } & \multicolumn{5}{|c|}{ Case2 (Urban Destination) } \\
\hline & $\begin{array}{l}\text { Indirect } \\
\text { Effects }\end{array}$ & Lower & Upper & $p$-Value & Results & $\begin{array}{l}\text { Indirect } \\
\text { Effects }\end{array}$ & Lower & Upper & $p$-Value & Results \\
\hline $\mathrm{DI} \rightarrow \mathrm{TS} \rightarrow \mathrm{TESB}$ & 0.021 & 0 & 0.072 & 0.045 & Supported & 0.024 & 0.003 & 0.064 & 0.02 & Supported \\
\hline $\mathrm{DI} \rightarrow \mathrm{TS} \rightarrow \mathrm{DT} \rightarrow \mathrm{TESB}$ & 0.005 & 0 & 0.018 & 0.031 & Supported & 0.005 & 0.001 & 0.018 & 0.02 & Supported \\
\hline $\mathrm{DI} \rightarrow \mathrm{DT} \rightarrow \mathrm{TESB}$ & 0.033 & 0.005 & 0.071 & 0.019 & Supported & 0.032 & 0.004 & 0.08 & 0.024 & Supported \\
\hline $\mathrm{DI} \rightarrow \mathrm{TS} \rightarrow \mathrm{TL}$ & 0.041 & 0.003 & 0.118 & 0.031 & Supported & 0.032 & 0.008 & 0.072 & 0.009 & Supported \\
\hline $\mathrm{DI} \rightarrow \mathrm{TS} \rightarrow \mathrm{DT} \rightarrow \mathrm{TL}$ & 0.006 & 0.001 & 0.019 & 0.022 & Supported & 0.01 & 0.003 & 0.024 & 0.001 & Supported \\
\hline $\mathrm{DI} \rightarrow \mathrm{DT} \rightarrow \mathrm{TL}$ & 0.043 & 0.015 & 0.085 & 0.003 & Supported & 0.061 & 0.026 & 0.115 & 0 & Supported \\
\hline
\end{tabular}

\subsection{Cross-Validation Test}

Compared with preceding analyses, the cross-validation approach is more insightful in showing a study's applicability and generalizability by testing it with different situations [90]. In order to test the robustness of the conceptualized model, cross-validation was performed between the rural and urban destinations. 
Hangzhou $\left(29^{\circ} 11^{\prime}-30^{\circ} 33^{\prime} \mathrm{N}, 118^{\circ} 21^{\prime}-120^{\circ} 30^{\prime} \mathrm{E}\right)$, the capital city of Zhejiang Province and adjacent to Anji, was the target (Figure 2.). Hangzhou is famous in history and culture and thus an important tourist city around the world. It is rich in tourist attractions and selected as one of the first batches of 15 National Culture and Tourism Consumption Models by the Ministry of Culture and Tourism in 2020. It has three World Heritage List sites, namely, West Lake, the Beijing-Hangzhou Grand Canal (southern end) and the Archaeological Ruins of Liangzhu City [91]. Among them, West Lake is the most famous. For centuries, it has enjoyed a reputation for its picturesque landscape, cultural heritage and legends passed from generation to generation [92]. Therefore, the urban case study was conducted in Hangzhou with the West Lake as the main site.

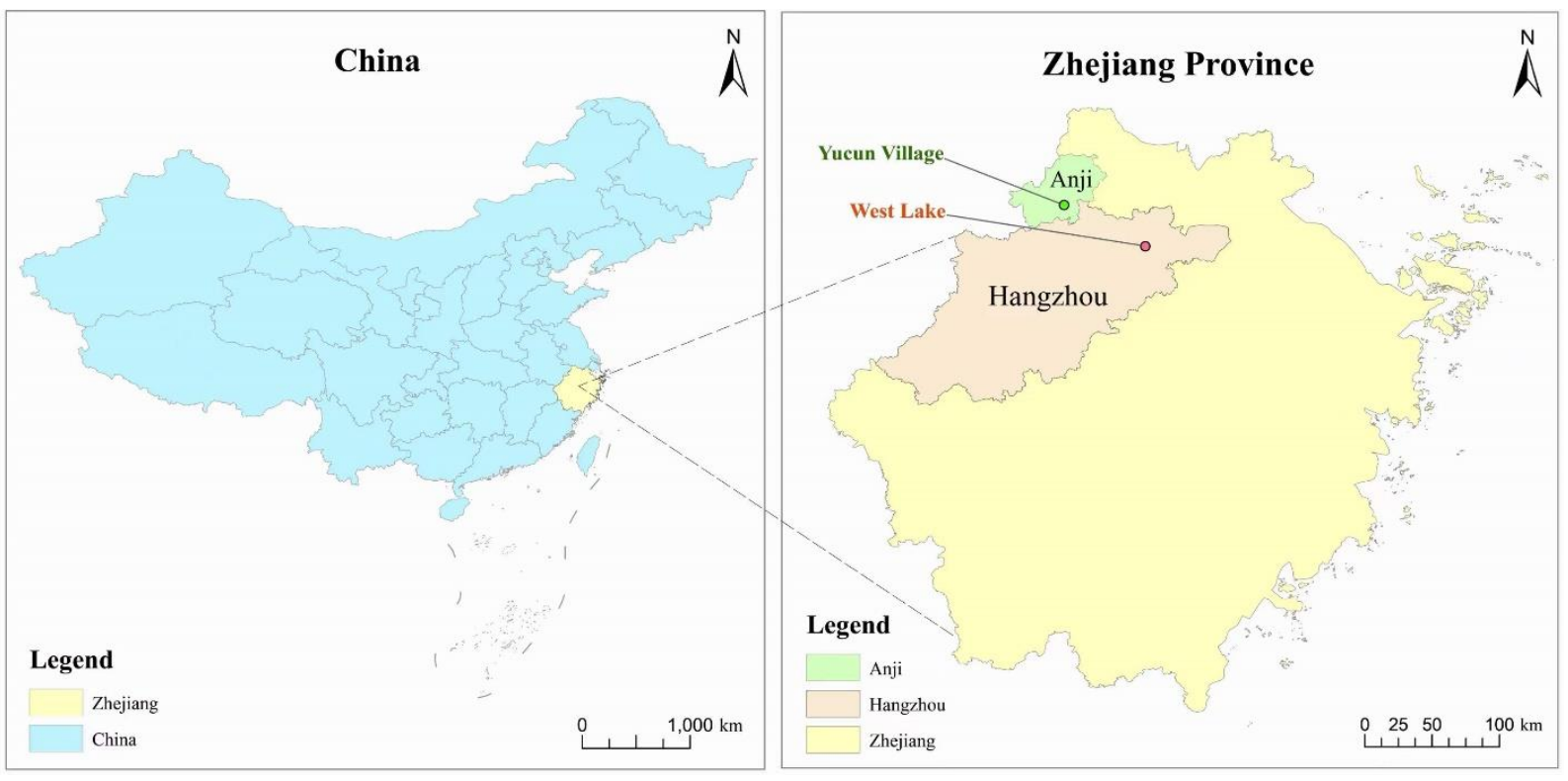

Figure 2. Geographical locations of Anji and Hangzhou.

Similar to the initial survey in a rural context, the data collection at the urban tourism destinations also concentrated on domestic tourists. Foreign tourists were not surveyed. A total of 400 questionnaires were collected. Of these, 370 usable responses were identified with a usable response rate of $92.5 \%$. Among the respondents, males accounted for $47.3 \%$ and females for 52.7\%; aged below 20 occupied 7.0\%; 20-29, 22.4\%; 30-39, 33.0\%; 40-49, $17.6 \%$; and 50 and above, $20.0 \%$. Middle school and below for education was $13.2 \%$; high school/secondary specialized school/technical school, $15.4 \%$; vocational college, $19.2 \%$; undergraduate, $43.2 \%$; and postgraduate and above, $8.9 \%$.

Normality, common method bias and validity and reliability tests all supported the conceptual model (Tables 2 and 3).

Respondents were divided into two groups: rural destination $(\mathrm{n}=373)$ and urban destination ( $\mathrm{n}=370)$. As per the guideline by Su and Swanson (2017) [93], the multi-group comparative analysis method in AMOS was employed and imported both groups' data and set up different conditions (i.e., measurement residual model, structural residual model, structural covariances model, structural weights model, measurement weight model and unconstrained model). Table 6 indicates an acceptable fit in all the tested models. In testing differences between the constrained and the unconstrained models (Table 7), no statistically significant differences were found $(p>0.05)$, providing tenable evidence in support of cross-validation. 
Table 6. Goodness of fit indices for all tested models.

\begin{tabular}{ccccccccc}
\hline Model & $\chi^{\mathbf{2}} / \mathbf{d f}$ & RMR & RMSEA & GFI & NFI & IFI & TLI & CFI \\
\hline Unconstrained & 1.969 & 0.015 & 0.036 & 0.934 & 0.952 & 0.976 & 0.97 & 0.976 \\
Measurement weights & 1.919 & 0.015 & 0.035 & 0.933 & 0.951 & 0.976 & 0.971 & 0.976 \\
Structural weights & 1.854 & 0.016 & 0.034 & 0.932 & 0.95 & 0.977 & 0.973 & 0.976 \\
Structural covariances & 1.847 & 0.016 & 0.034 & 0.932 & 0.95 & 0.977 & 0.974 & 0.977 \\
Structural residuals & 1.829 & 0.017 & 0.033 & 0.932 & 0.95 & 0.977 & 0.974 & 0.977 \\
Measurement residuals & 1.798 & 0.017 & 0.033 & 0.929 & 0.948 & 0.976 & 0.975 & 0.976 \\
\hline
\end{tabular}

Table 7. Significance of tested models compared to unconstrained model.

\begin{tabular}{cccccccc}
\hline Model & DF & $\chi^{2}$ & $p$ & $\begin{array}{c}\text { NFI } \\
\text { Delta-1 }\end{array}$ & $\begin{array}{c}\text { IFI } \\
\text { Delta-2 }\end{array}$ & $\begin{array}{c}\text { RFI } \\
\text { Rho-1 }\end{array}$ & $\begin{array}{c}\text { TLI } \\
\text { Rho-2 }\end{array}$ \\
\hline Measurement weights & 12 & 12.116 & 0.436 & 0.001 & 0.001 & -0.001 & -0.002 \\
Structural weights & 21 & 13.753 & 0.88 & 0.002 & 0.002 & -0.003 & -0.004 \\
Structural covariances & 22 & 13.768 & 0.91 & 0.002 & 0.002 & -0.004 & -0.004 \\
Structural residuals & 26 & 16.754 & 0.916 & 0.002 & 0.002 & -0.004 & -0.004 \\
Measurement residuals & 43 & 39.629 & 0.618 & 0.004 & 0.005 & -0.005 & -0.005 \\
\hline
\end{tabular}

The nine hypotheses of the conceptual model presented in Figure 1 were supported in the urban context (Table 4), based on which all the mediation effects were proven (Table 5). The output results of AMOS in rural and urban contexts are presented in Figure 3.

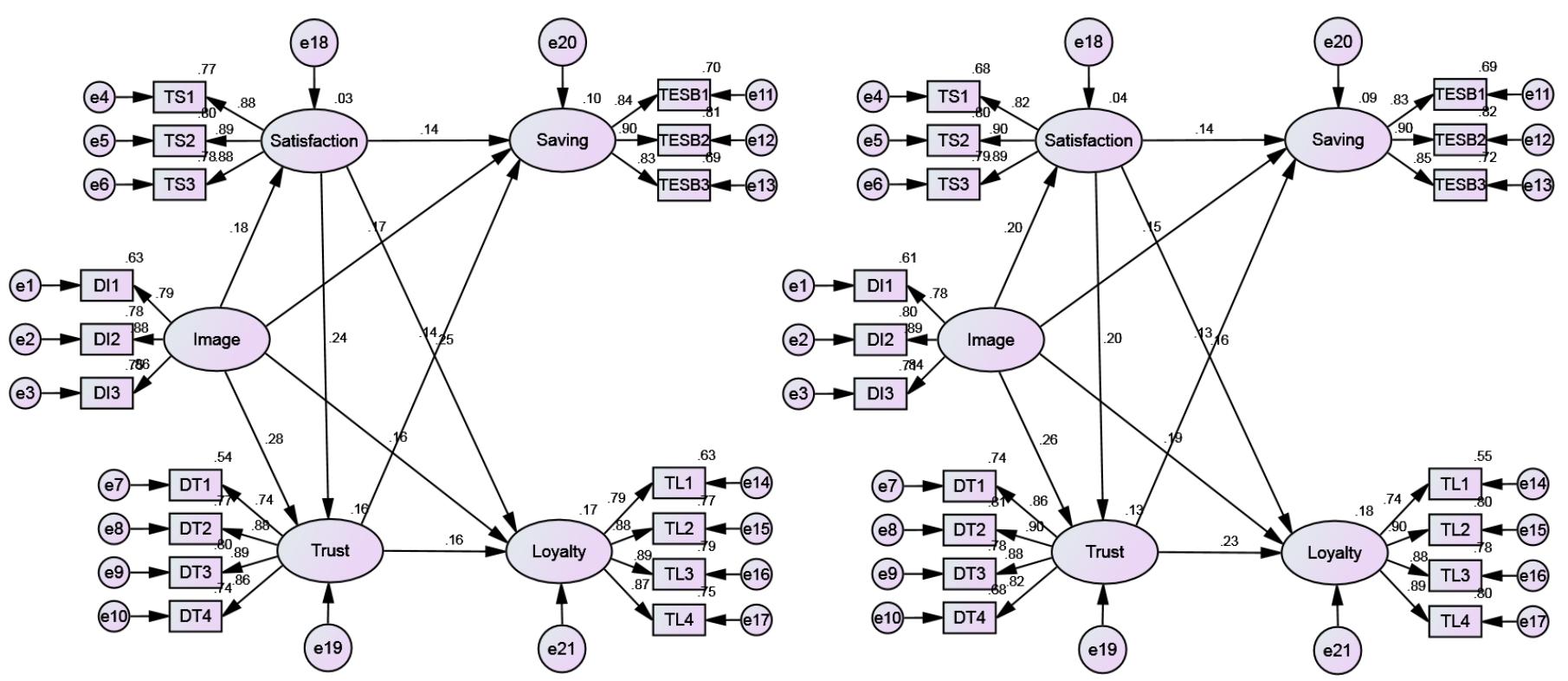

Figure 3. Output results of AMOS in rural (Left) and urban (Right) contexts.

\section{Conclusions, Contributions and Implications}

\subsection{Conclusions}

This research applied the cognition-affect-behavior model to examine the relationship between tourist energy-saving behavior and loyalty at rural tourism destinations. The cross-validation results verified the theoretical framework and identified causal links among antecedents of energy-saving behavior and loyalty. Specifically, the findings were as follows:

First, both SEM and cross-validation outcomes showed that destination image exerted a significant and positive influence on tourist energy-saving behavior and loyalty, which on the one hand, confirmed the prior research on the relationship between destination image 
and loyalty [11]; on the other hand, extended the literature by revealing the connection between destination image and specific tourist pro-environmental behavior [12,13]. This finding attached considerable importance to destination image's contribution to rural and urban land destination sustainable development. It is pivotal to investigate the role of destination image in predicting tourist satisfaction and destination trust, which further contribute to energy-saving behavior and loyalty.

Second, the empirical results demonstrated that tourist satisfaction and destination trust were constructive relationship quality variables to have mediation effects on the associations of destination image with tourist energy-saving behavior and loyalty. In line with the CAB model, the claim that both variables as two of the most frequently used constructs concerning relationship quality were evidenced, and their validity in predicting loyalty was also confirmed [11,57]. More importantly, the destination image literature was enriched by indicating the linkage between relationship quality variables and energysaving behavior, which indicated that tourists are willing to practice energy-saving if they are satisfied with and trust the destination.

Third, the cross-validation analysis displayed that this approach was fit for destination image research. The initial survey was performed in a rural land area and later reexamined in a city location, both of which successfully verified the robustness of the conceptual model. Especially the latter, by adopting a cross-validation approach increased generalizability and demonstrated stronger explanatory power for these research findings.

\subsection{Theoretical Contributions}

First, the research extends the application of the cognition-affect-behavior $(\mathrm{CAB})$ model to rural tourism. This model has demonstrated its power in a wide range of domains [28], but rural land research has remained insufficient. By taking destination image as the cognitive factor and relationship quality variables, i.e., satisfaction and destination trust as affective factors, the research successfully examined energy-saving behavior and loyalty. The cross-validation method also provided empirical evidence for the effectiveness of the CAB model. Consistent with prior studies [11,57], this research extends the applicability of the $\mathrm{CAB}$ model to rural tourism, for it was found to fit with the exploration of destination image as a driver of energy-saving behavior and loyalty.

Second, this study enriches the destination image literature by including energysaving behavior and provides an original perspective to address energy consumption reduction and destination sustainability in tourism. This finding confirmed the relationship between pro-environmental destination image and pro-environmental behavior [12,13]. More importantly, it enlarges the influence of destination image from mainly loyaltyfocused behavior to pro-environmental behavior and included energy-saving behavior as a segment of the latter, a specific pro-environmental behavior. Despite the fact that energy consumption is at the core of the tourism industry, there has been lesser debate about the nexus of energy use and tourism destination management [94], especially regarding tourist contributions to energy-saving and efficiency. Generally, tourists represent a major consumer segment for destinations [95]. Tourist energy-saving performance helps promote destination energy consumption reduction, and moreover, as individual practices at the micro-economic level, fuels energy efficiency presently observed at the macro-economic level to make joint efforts towards tourism sustainability [96]. This study adds to the current literature from a micro perspective, highlighting the importance of tourists in the promotion of tourism sustainability; specifically, the overall image perceived by tourists played an important role in energy-saving and carbon emission reduction at destinations.

Third, a cross-validation approach was introduced and added to the current destination image literature. Although the results from preceding analyses are both important and necessary, whether they remain constant under different conditions are unknown. The cross-validation approach is insightful due to showing a study's applicability to different situations, which increases a theory's predictive scope [90]. The robustness analysis of the cross-validation approach performed in this research enhanced the generalizability of the 
conceptual model with different samples and contexts. The results indicated that the model was invariant across samples, which implied that destination image tended to be a stable factor in driving energy-saving behavior and loyalty. It improved the research value by initiating a new methodology in the destination image literature.

\subsection{Managerial Implications}

The importance of this study is not only reflected in the academic contributions from the perspectives of theory, content and methodology as discussed in the previous section; it also offers important implications for the sustainable management of tourism destinations. Be it rural or urban land tourism destinations, enhancing tourist loyalty and energy conservation behavior is crucial and indispensable for sustainable development. Destination development relies on tourist revisits and positive word-of-mouth; however, a constant influx of tourists inevitably causes significant energy consumption, which hinders destination sustainability, casting a potentially lasting negative impact on the attractiveness of destinations. The empirical results also demonstrated that the overall image perceived by tourists exercised a positive influence on their energy-saving behavior and loyalty at destinations, which provides an important fundamental for promoting the sustainable management of destinations.

First, destinations should enhance their images in multiple ways. It is better for destinations, especially rural ones, to include a professional management agency responsible for integrating resources and coordination to ensure the establishment of quality tourism and a strong, competitive image. Destination managers must identify and communicate images. When marketing, for instance, they could strategically picture the destination by focusing on uniqueness to achieve differentiation. They should also strive to design fascinating travel experiences accompanied by impressive products and services. For example, with a joint effort from experts and residents, they could transform public places into activity centers and living museums based on local resources. Moreover, it is suggested that corporate social responsibility (CSR) practices help improve destination images and increase loyalty and satisfaction [97]. Additionally, if carbon reduction elements are added to cultivate green settings and atmospheres, this is more likely to motivate tourists to engage in energy-saving [13].

Second, tourism destinations should also make efforts to strengthen tourist satisfaction. The research findings indicated achieving satisfaction was of great importance, for on the one hand, just as prior studies suggested, satisfied tourists were more inclined to trust the destination [11]; on the other hand, considering delivering superior satisfaction increases the possibility of promoting pro-environmental behavior [98], tourist satisfaction can ensure tourist energy-saving behavior and loyalty. Destination operators need to provoke and maintain positive emotions all the way. For example, positive reviews made by previous visitors should be given priority because they are the most reliable information source to potential tourists. Popular social media platforms, such as microblogs and TikTok, are ideal marketing battlefields where tourist complaints should be dealt with effectively and post-trip feedback is warmly welcomed. Furthermore, destination managers should always bear the purpose of enhancing satisfaction by designing tourism policies, infrastructure and activities for the purpose of making tourists feel important, comfortable and respected.

Third, all destination service providers should devote themselves to developing trust. Tour operations, ground transportation, airlines, hotels and restaurants should be educated that their service quality and performance determine trust towards the destination. For example, rural tourism often entails close host-tourist interactions; therefore, host-positive behaviors can improve travel experiences [99] and are more likely to garner trust. Additionally, destination operators should ensure that their intrinsic motives for launching pro-environmental activities are clearly communicated to tourists, which will ultimately strengthen tourist trust in the destination. They can enhance energy-saving behavior by gaining their trust in activities, for instance, encouraging tourists to participate in carbon reduction initiatives to support destination sustainability. The results suggest that tourists 
who trust the destination tend to engage in energy-saving and have greater loyalty if they believe the destination policy initiatives are credible [58].

\section{Limitations and Future Research Directions}

First, this research used self-reported measurements, which have a potential danger of social desirability effects. Future research should conduct observations or arrange interviews. Second, because both cases focused on domestic tourists, this did not fully reflect the entire tourist population at the survey sites. Therefore, when conducting on-site surveys, it would be better to include tourists with different nationalities. In addition, diverse destinations in different regions and countries could be considered in the following studies. Third, there is much room for exploring more segment pro-environmental behaviors, e.g., water-saving and food waste reduction, which will further enrich the research.

Author Contributions: Conceptualization, H.Q. and X.Z.; methodology, H.Q. and W.W.; software, H.Q. and W.W.; validation, H.Q. and A.M.M.; formal analysis, H.Q. and X.Z.; investigation, W.Z.; data curation, H.Q. and W.Z.; writing — original draft preparation, W.Z. and H.Q.; writing-review and editing, A.M.M. All authors have read and agreed to the published version of the manuscript.

Funding: This research was funded by the Youth Foundation of Humanities and Social Science Project of the Ministry of Education of China (grant number: 19YJC630131); the Youth Key Project of Premier Humanities and Social Science Program for Higher Educational Institutes of Zhejiang Province, China (grant number: 2018QN015); and the General Research Project of the Department of Education of Zhejiang Province (grant number: Y202147320).

Data Availability Statement: Not applicable.

Conflicts of Interest: The authors declare no conflict of interest.

\section{References}

1. Chi, X.; Han, H. Emerging rural tourism in China's current tourism industry and tourist behaviors: The case of Anji County. J. Travel Tour. Mark. 2021, 38, 58-74. [CrossRef]

2. Rosalina, P.D.; Dupre, K.; Wang, Y. Rural tourism: A systematic literature review on definitions and challenges. J. Hosp. Tour. Manag. 2021, 47, 134-149. [CrossRef]

3. da Silva Lopes, H.; Remoaldo, P.C.; Ribeiro, V.; Martín-Vide, J. Effects of the COVID-19 pandemic on tourist risk perceptionsthe case study of Porto. Sustainability 2021, 13, 6399. [CrossRef]

4. Mwesiumo, D.; Halfdanarson, J.; Shlopak, M. Navigating the early stages of a large sustainability-oriented rural tourism development project: Lessons from Træna, Norway. Tour. Manag. 2022, 89, 104456. [CrossRef]

5. Peric, M.; Djurkin, J. Systems thinking and alternative business model for responsible tourist destination. Kybernetes 2014, 43 , 480-496. [CrossRef]

6. Cavalcante, W.Q.d.F.; Coelho, A.; Bairrada, C.M. Sustainability and Tourism Marketing: A Bibliometric Analysis of Publications between 1997 and 2020 Using VOSviewer Software. Sustainability 2021, 13, 4987. [CrossRef]

7. López-Sanz, J.M.; Penelas-Leguía, A.; Gutiérrez-Rodríguez, P.; Cuesta-Valiño, P. Sustainable Development and Rural Tourism in Depopulated Areas. Land 2021, 10, 985. [CrossRef]

8. An, W.; Alarcón, S. How Can Rural Tourism Be Sustainable? A Systematic Review. Sustainability 2020, 12, 7758. [CrossRef]

9. Foroudi, P.; Akarsu, T.N.; Ageeva, E.; Foroudi, M.M.; Dennis, C.; Melewar, T.C. Melewar PROMISING THE DREAM: Changing destination image of London through the effect of website place. J. Bus. Res. 2018, 83, 97-110. [CrossRef]

10. Kim, S.-K.; Park, J.-A.; Kim, W. The Mediating Effect of Destination Image on the Relationship Between Spectator Satisfaction and Behavioral Intentions at an International Sporting Event. Asia Pac. J. Tour. Res. 2016, 21, 273-292. [CrossRef]

11. Su, L.; Hsu, M.K.; Swanson, S. Relationship perception on destination loyalty at a world heritage site in China: The mediating role of overall destination satisfaction and trust. J. Hosp. Tour. Res. 2017, 41, 180-210. [CrossRef]

12. Lee, W.; Jeong, C. Effects of pro-environmental destination image and leisure sports mania on motivation and pro-environmental behavior of visitors to Korea's national parks. J. Destin. Mark. Manag. 2018, 10, 25-35. [CrossRef]

13. Zhang, J.; Xie, C.; Morrison, A.M.; Zhang, K. Fostering Resident Pro-Environmental Behavior: The Roles of Destination Image and Confucian Culture. Sustainability 2020, 12, 597. [CrossRef]

14. Dolnicar, S.; Leisch, F. Selective marketing for environmentally sustainable tourism. Tour. Manag. 2008, 29, 672-680. [CrossRef]

15. Li, Q.; Wu, M. Tourists' pro-environmental behaviour in travel destinations: Benchmarking the power of social interaction and individual attitude. J. Sustain. Tour. 2020, 28, 1371-1389. [CrossRef]

16. Horng, J.-S.; Hu, M.-L.M.; Teng, C.-C.C.; Lin, L. Energy Saving and Carbon Reduction Behaviors in Tourism-A Perception Study of Asian Visitors from a Protection Motivation Theory Perspective. Asia Pac. J. Tour. Res. 2014, 19, 721-735. [CrossRef] 
17. Zhang, C.Y.; Yu, B.; Wang, J.W.; Wei, Y.M. Impact factors of household energy-saving behavior: An empirical study of Shandong Province in China. J. Clean. Prod. 2018, 185, 285-298. [CrossRef]

18. Laroche, M.; Hui, M.; Zhou, L. A Test of the Effects of Competition on Consumer Brand Selection Processes. J. Bus. Res. 1994, 31, 171-181. [CrossRef]

19. Rahman, I.; Park, J.; Chi, C.G. Consequences of "greenwashing": Consumers' reactions to hotels' green initiatives. Int. J. Contemp. Hosp. M. 2015, 27, 1054-1081. [CrossRef]

20. Chen, Q.; Mao, Y.; Morrison, A.M. The Influence of Land Use Evolution on the Visitor Economy in Wuhan from the Perspective of Ecological Service Value. Land 2022, 11, 1. [CrossRef]

21. Ashworth, G.; Page, S.J. Urban tourism research: Recent progress and current paradoxes. Tour. Manag. 2011, 32, 1-15. [CrossRef]

22. Füller, H.; Michel, B. 'Stop Being a Tourist!' New Dynamics of Urban Tourism in Berlin-Kreuzberg. Int. J. Urban Regional. 2014, 38, 1304-1318. [CrossRef]

23. Fishbein, M.; Ajzen, I. (Eds.) Predicting and Understanding Consumer Behavior: Attitude-behavior correspondence. In Understanding Attitudes and Predicting Social Behavior; Prentice Hall: Englewood Cliffs, NJ, USA, 1980; pp. 148-172.

24. Weiner, B. An Attributional Theory of Motivation and Emotion; Springer: New York, NY, USA, 1986.

25. Dweck, C.S.; Leggett, E.L. A social-cognitive approach to motivation and personality. Psychol. Rev. 1988, 95, 256-273. [CrossRef]

26. Huang, G.H.; Korfiatis, N.; Chang, C.T. Mobile shopping cart abandonment: The roles of conflicts, ambivalence, and hesitation. J. Bus. Res. 2018, 85, 165-174. [CrossRef]

27. Poulou, M.; Norwich, B. Cognitive, Emotional and Behavioural Responses to Students with Emotional and Behavioural Difficulties: A model of decision-making. Brit. Educ. Res. J. 2002, 28, 111-138. [CrossRef]

28. Chen, A.; Lu, Y.; Gupta, S.; Qi, X. Can customer satisfaction and dissatisfaction coexist? An issue of telecommunication service in China. J. Inf. Technol. 2014, 29, 237-252. [CrossRef]

29. Ribeiro, M.A.; Prayag, G. Perceived quality and service experience: Mediating effects of positive and negative emotions. J. Hosp. Market. Manag. 2019, 28, 285-305. [CrossRef]

30. Chou, S.-F.; Horng, J.-S.; Liu, C.-H.S.; Lin, J.-Y. Identifying the critical factors of customer behavior: An integration perspective of marketing strategy and components of attitudes. J. Retail. Consum. Serv. 2020, 55, 102113. [CrossRef]

31. Cheng, X.; Gu, Y.; Mou, J. Interpersonal relationship building in social commerce communities: Considering both swift guanxi and relationship commitment. Electron. Commer. Res. 2020, 20, 53-80. [CrossRef]

32. Crompton, J.L. An assessment of the image of Mexico as a vacation destination and the influence of geographical location upon that image. J. Travel Res. 1979, 17, 18-23. [CrossRef]

33. Marine-Roig, E. Measuring Online Destination Image, Satisfaction, and Loyalty: Evidence from Barcelona Districts. Tour. Hosp. 2021, 2, 62-78. [CrossRef]

34. Echtner, C.M.; Ritchie, J.R.B. The Measurement of Destination Image: An Empirical Assessment. J. Travel Res. 1993, 31, 3-13. [CrossRef]

35. Pereira, M.L.; Anjos, F.A.; Añaña, E.S.; Weismayer, C. Modelling the overall image of coastal tourism destinations through personal values of tourists: A robust regression approach. J. Outdoor Rec. Tour. 2021, 35, 100412. [CrossRef]

36. Zhang, H.; Fu, X.; Cai, L.A.; Lu, L. Destination image and tourist loyalty: A meta-analysis. Tour. Manag. 2014, 40, 213-223. [CrossRef]

37. Afshardoost, M.; Eshaghi, M.S. Destination image and tourist behavioural intentions: A meta-analysis. Tour. Manag. 2020, 81, 104154. [CrossRef]

38. Prayag, G.; Hosany, S.; Muskat, B.; Chiappa, G.D. Understanding the Relationships between Tourists' Emotional Experiences, Perceived Overall Image, Satisfaction, and Intention to Recommend. J. Travel Res. 2015, 56, 41-54. [CrossRef]

39. Marine-Roig, E. Destination Image Analytics Through Traveller-Generated Content. Sustainability 2019, 11, 3392. [CrossRef]

40. Souiden, N.; Ladhar, R.; Chiadmi, N.E. Destination personality and destination image. J. Hosp. Tour. Manag. 2017, 32, 54-70. [CrossRef]

41. Li, T.T.; Liu, F.; Soutar, G.F. Experiences, post-trip destination image, satisfaction and loyalty: A study in an ecotourism context. J. Destin. Mark. Manag. 2021, 19, 100547. [CrossRef]

42. Park, S.H.; Hsieh, C.-M.; Lee, C.-K. Examining Chinese College Students' Intention to Travel to Japan Using the Extended Theory of Planned Behavior: Testing Destination Image and the Mediating Role of Travel Constraints. J. Travel Tour. Mark. 2017, 34, 113-131. [CrossRef]

43. VG, G.; Park, E. Testing the influence of destination source credibility, destination image, and destination fascination on the decision-making process: Case of the Cayman Islands. Int. J. Tour. Res. 2020, 23, 569-580.

44. Choi, S.; Lehto, X.Y.; Morrison, A.M. Destination image representation on the web: Content analysis of Macau travel related websites. Tour. Manag. 2007, 28, 118-129. [CrossRef]

45. Chen, C.-F.; Phou, S. A closer look at destination: Image, personality, relationship and loyalty. Tour. Manag. 2013, 36, 269-278. [CrossRef]

46. Sheth, J.N.; Parvatiyar, A. The evolution of relationship marketing. Int. Bus. Rev. 1995, 4, 397-418. [CrossRef]

47. Alves, H.; Campón-Cerro, A.M.; Hernández-Mogollón, J.M. Enhancing rural destinations' loyalty through relationship quality. Span. J. Mark. ESIC 2019, 23, 185-204. [CrossRef] 
48. Su, L.; Wang, L.; Law, R.; Chen, X.; Fong, D. Influences of destination social responsibility on the relationship quality with residents and destination economic performance. J. Travel. Tour. Mark. 2017, 34, 488-502. [CrossRef]

49. Lam, I.K.V.; Wong, I.A. The role of relationship quality and loyalty program in tourism shopping: A multilevel investigation. J. Travel. Tour. Mark. 2020, 37, 92-111. [CrossRef]

50. Dorsch, M.J.; Swanson, S.R.; Kelley, S.W. The role of relationship quality in the stratification of vendors as perceived by customers. J. Acad. Market. Sci. 1998, 26, 128-142. [CrossRef]

51. Wu, H.-C.; Cheng, C.-C. Relationships between technology attachment, experiential relationship quality, experiential risk and experiential sharing intentions in a smart hotel. J. Hosp. Tour. Manag. 2018, 37, 42-58. [CrossRef]

52. Kozak, M.; Rimmington, M. Tourist Satisfaction with Mallorca, Spain, as an Off-Season Holiday Destination. J. Travel Res. 2000, 38, 260-269. [CrossRef]

53. Beard, J.G.; Ragheb, M.G. Measuring leisure satisfaction. J. Leis. Res. 1980, 12, 20-33. [CrossRef]

54. Su, L.; Lian, Q.; Huang, Y. How do tourists' attribution of destination social responsibility motives impact trust and intention to visit? The moderating role of destination reputation. Tour. Manag. 2020, 77, 103970. [CrossRef]

55. Chi, C.G.-Q.; Wen, B.; Zhe, O. Developing relationship quality in economy hotels: The role of perceived justice, service quality, and commercial friendship. J. Hosp. Market. Manag. 2020, 29, 1027-1051. [CrossRef]

56. Ravald, A.; Grönroos, C. The value concept and relationship marketing. Eur. J. Mark. 1996, 30, 19-30. [CrossRef]

57. Loureiro, S.M.C.; González, F.J.M. The Importance of Quality, Satisfaction, Trust, and Image in Relation to Rural Tourist Loyalty. J. Travel Tour. Mark. 2008, 25, 117-136. [CrossRef]

58. Song, Z.; Daryanto, A.; Soopramanien, D. Place attachment, trust and mobility: Three-way interaction effect on urban residents environmental citizenship behaviour. J. Bus. Res. 2019, 105, 168-177. [CrossRef]

59. Ramkissoon, H.; Mavondo, F.T. Pro-environmental behavior: Critical link between satisfaction and place attachment in Australia and Canada. Tour. Anal. 2017, 22, 59-73. [CrossRef]

60. Rizzi, F.; Annunziata, E.; Contini, M.; Frey, M. On the effect of exposure to information and self-benefit appeals on consumer's intention to perform pro-environmental behaviours: A focus on energy conservation behaviours. J. Clean. Prod. 2020, $270,122039$. [CrossRef]

61. Wang, Q.C.; Chang, R.; Xu, Q.; Liu, X.; Jian, I.Y.; Ma, T.M.; Wang, Y.X. The impact of personality traits on household energy conservation behavioral intentions-An empirical study based on theory of planned behavior in Xi'an. Sustain. Energy Technol. 2021, 43, 100949. [CrossRef]

62. Xu, X.; Xiao, B.; Li, C.Y. Analysis of critical factors and their interactions influencing individual's energy conservation behavior in the workplace: A case study in China. J. Clean. Prod. 2021, 286, 124955. [CrossRef]

63. Wang, Q.-C.; Xie, K.-X.; Liu, X.; Shen, G.Q.P.; Wei, H.-H.; Liu, T.-Y. Psychological Drivers of Hotel Guests' Energy-Saving Behaviours-Empirical Research Based on the Extended Theory of Planned Behaviour. Buildings 2021, 11, 401. [CrossRef]

64. Du, J.; Pan, W. Examining energy saving behaviors in student dormitories using an expanded theory of planned behavior. Habitat. Int. 2021, 107, 102308. [CrossRef]

65. Zhu, J.; Zhao, X.; Zhu, T.; Li, L. Which factors determine students' water-saving behaviors? Evidence from China colleges. Urban Water J. 2021, 18, 860-872. [CrossRef]

66. Mardani, A.; Zavadskas, E.K.; Streimikiene, D.; Jusoh, A.; Nor, K.M.D.; Khoshnoudi, M. Using fuzzy multiple criteria decisionmaking approaches for evaluating energy saving technologies and solutions in five star hotels: A new hierarchical framework Energy 2016, 117, 131-148. [CrossRef]

67. Shaykh-Baygloo, R. A multifaceted study of place attachment and its influences on civic involvement and place loyalty in Baarestan new town, Iran. Cities 2020, 96, 102473. [CrossRef]

68. Mirzaalian, F.; Halpenny, E. Exploring destination loyalty: Application of social media analytics in a nature-based tourism setting. J. Destin. Mark. Manag. 2021, 20, 100598. [CrossRef]

69. Sirgy, J.M.; Su, C. Destination Image, Self-Congruity, and Travel Behavior: Toward an Integrative Model. J. Travel Res. 2000, 38, 340-352. [CrossRef]

70. Chaulagain, S.; Wiitala, J.; Fu, X. The impact of country image and destination image on US tourists' travel intention. J. Destin. Mark. Manag. 2019, 12, 1-11. [CrossRef]

71. Chiu, Y.-T.H.; Lee, W.-I.; Chen, T.-H. Environmentally Responsible Behavior in Ecotourism: Exploring the Role of Destination Image and Value Perception. Asia Pac. J. Tour. Res. 2014, 19, 876-889. [CrossRef]

72. Fu, L.; Sun, Z.; Zha, L.; Liu, F.; He, L.; Sun, X.; Jing, X. Environmental Awareness and Pro-environmental Behavior within China's Road Freight Transportation Industry: Moderating Role of Perceived Policy Effectiveness. J. Clean. Prod. 2020, 252, 119796. [CrossRef]

73. Nguyen, N.; Leblanc, G. Corporate image and corporate reputation in customers' retention decisions in services. J. Retail Consum. Serv. 2001, 8, 227-236. [CrossRef]

74. Kim, K.-H.; Park, D.-B. Relationships among Perceived Value, Satisfaction, and Loyalty: Community-Based Eco tourism in Korea. J. Travel Tour. Mark. 2017, 34, 171-191. [CrossRef]

75. Wu, H.-C.; Cheng, C.-C.; Ai, C.-H. A study of experiential quality, experiential value, trust, corporate reputation, experiential satisfaction and behavioral intentions for cruise tourists: The case of Hong Kong. Tour. Manag. 2018, 66, 200-220. [CrossRef] 
76. Han, H.; Lee, M.J.; Kim, W. Role of shopping quality, hedonic/utilitarian shopping experiences, trust, satisfaction and perceived barriers in triggering customer post-purchase intentions at airports. Int. J. Contemp. Hosp. Manag. 2018, 30, 3059-3082. [CrossRef]

77. Lopes, J.R.N.; de Araújo Kalid, R.; Rodrígueza, J.L.M.; Filho, S.A. A new model for assessing industrial worker behavior regarding energy saving considering the theory of planned behavior, norm activation model and human reliability. Resour. Conserv. Recycl. 2019, 145, 268-278. [CrossRef]

78. Lee, Y.-K.; Lee, C.-K.; Choi, J.; Yoon, S.-M.; Hart, R.J. Tourism's role in urban regeneration: Examining the impact of environmental cues on emotion, satisfaction, loyalty, and support for Seoul's revitalized Cheonggyecheon stream district. J. Sustain. Tour. 2014, 22, 726-749. [CrossRef]

79. Lee, Y.-K. Impact of government policy and environment quality on visitor loyalty to Taiwan music festivals: Moderating effects of revisit reason and occupation type. Tour. Manag. 2016, 53, 187-196. [CrossRef]

80. Anji County. Available online: http:/ / www.huzhou.gov.cn/art/2013/1/7/art_1229213980_54840421.html (accessed on 8 December 2021).

81. Anji Yucun Village: Being "Green, Rich, and Beautiful" Thanks to the "Two Mountains" Concept. Available online: https: //www.mct.gov.cn/whzx/qgwhxxlb/zj/202004/t20200410_852414.htm (accessed on 8 December 2021).

82. Unwto Announces List of Best Tourism Villages. 2021. Available online: https://www.unwto.org/news/unwto-announces-listof-best-tourism-villages-2021 (accessed on 8 December 2021).

83. Kline, R.B. Principles and Practice of Structural Equation Modeling; Guilford: New York, NY, USA, 1998.

84. He, M.; Liu, B.; Li, Y. Tourist Inspiration: How the Wellness Tourism Experience Inspires Tourist Engagement. J. Hosp. Tour. Res. 2021. [CrossRef]

85. Podsakoff, P.M.; Organ, D.W. Self-reports in organizational research: Problems and prospects. J. Manag. 1986, 12, 531-544. [CrossRef]

86. Anderson, J.C.; Gerbing, D.W. Structural equation modeling in practice: A review and recommended two-step approach. Psychol. Bull 1988, 103, 411-423. [CrossRef]

87. Nunnally, J.C. Psychometric Theory; McGraw-Hill: New York, NY, USA, 1978.

88. Hair, J.F.; Black, W.C.; Babin, B.J.; Anderson, R.E. Multivariate Data Analysis, 7th ed.; Prentice Hall: New York, NY, USA, 2009.

89. Fornell, C.; Larcker, D.F. Evaluating structural equation models with unobservable variables and measurement error. J. Mark. Res. 1981, 18, 39-50. [CrossRef]

90. Iniesta-Bonillo, M.A.; Sánchez-Fernández, R.; Jiménez-Castillo, D. Sustainability, value, and satisfaction: Model testing and cross-validation in tourist destinations. J. Bus. Res. 2016, 69, 5002-5007. [CrossRef]

91. Honorary Titles. Available online: http:/ / eng.hangzhou.gov.cn/art/2021/5/31/art_1229498050_58875569.html (accessed on 23 December 2021).

92. General Survey of West Lake. Available online: http:/ / westlake.hangzhou.gov.cn/col/col1629172/index.html (accessed on 23 December 2021).

93. Su, L.; Swanson, S.R. The effect of destination social responsibility on tourist environmentally responsible behavior: Compared analysis of first-time and repeat tourists. Tour. Manag. 2017, 60, 308-321. [CrossRef]

94. Becken, S.; Simmons, D.G.; Frampton, C. Energy use associated with different travel choices. Tour. Manag. 2003, 24, 267-277. [CrossRef]

95. Li, Y.; Filimonau, V.; Wang, L.; Cheng, S. Tourist food consumption and its arable land requirements in a popular tourist destination. Resour. Conserv. Recycl. 2020, 153, 104587. [CrossRef]

96. He, L.; Zha, J.; Loo, H.A. How to improve tourism energy efficiency to achieve sustainable tourism: Evidence from China. Curr. Issues Tour. 2020, 23, 1-16. [CrossRef]

97. Li, Y.; Fang, S.; Huan, T.-C.T. Consumer response to discontinuation of corporate social responsibility activities of hotels. Int. J. Hosp. Manag. 2017, 64, 41-50. [CrossRef]

98. Ramkissoon, H.; Mavondo, F.T. The satisfaction-place attachment relationship: Potential mediators and moderators. J. Bus. Res. 2021, 68, 2593-2602. [CrossRef]

99. Wu, M.-Y.; Wu, X.; Li, Q.-C.; Tong, Y. Community citizenship behavior in rural tourism destinations: Scale development and validation. Tour. Manag. 2022, 89, 104457. [CrossRef] 